\title{
Investigation of Perceptions regarding Teacher Leadership among Secondary School Teachers in Turkey
}

\author{
Bahadır Gülbahar ${ }^{1}$ \\ ${ }^{1}$ Social Sciences and Turkish Teaching Department at the Ahi Evran University Faculty of Education, Terme Caddesi, \\ Kirsehir, 40100, Turkey \\ Correspondence: Bahadır Gülbahar, Social Sciences and Turkish Teaching Department at the Ahi Evran University \\ Faculty of Education, Terme Caddesi, Kirsehir, 40100, Turkey.
}

Received: December 5, 2016

Accepted: January 4, 2017

Online Published: January 10, 2017

doi:10.11114/jets.v5i2.2040

URL: http://dx.doi.org/10.11114/jets.v5i2.2040

\begin{abstract}
Leadership is one of the most important roles expected from teachers today. Teacher leadership is a significant factor in the commitment of schools to their missions to guide societies, to develop a school's positive aspects and to manage education in an effective way. If this is the case, it is necessary to measure and evaluate the perceptions of teachers with regard to this important role. As yet there is limited amount of research in the literature concerning the determination of teachers' perceptions regarding teacher leadership. As the basic purpose of the present study is to determine the leadership perceptions of secondary school teachers, it is considered that the study will contribute to the literature. This qualitative research was conducted using the screening model. The study was conducted on 376 secondary school teachers who were selected by means of the simple random sampling method from among 564 teachers who were working at secondary schools in Kırşehir Central County (Turkey) during the 2014-2015 academic year. The "Teacher Leadership Scale" (TLS) was used as the data collection tool. Although the teachers' "institutional development" sub-dimension perception regarding teacher leadership was found to be at the middle level, this was assessed to be a lacking notation. Teachers' perception of teacher leadership for the "institutional improvement" sub-dimension was determined to be at the medium level; perceptions concerning "professional development" and "collaboration among colleagues" sub-dimensions were determined to be at a high level. Teachers' understanding of teacher leadership in terms of the "institutional improvement" sub-dimension exhibited a significant difference in male teachers. Teachers' perception of teacher leadership in terms of the "professional improvement" sub-dimension exhibited a significant difference according to age and occupational seniority.
\end{abstract}

Keywords: teacher roles, educational leadership, secondary schools, teacher perceptions

\section{Introduction}

Similarly to other organizations, schools are affected by the fast-paced change that we are experiencing today. This change requires an organization which is able to take on new roles, and makes schools so complicated that they cannot be managed by a single person (Kuran, 2005; Turan, 2010). The complicated nature of the responsibilities and the workloads of principals increase the threshold level for relevant skills and competencies and can make it difficult for principals to undertake their management and leadership responsibilities. These developments have resulted in some loss of the validity of conventional leadership in schools, and the contribution of all parties to leadership has necessitated that all stakeholders take responsibility for this process (Fullan, 1994; Hallinger, 2005; Harris, 2004). In the leadership process in schools, teachers are expected to participate alongside families and students (Anderson, 2004). The fact that teachers are the group which establishes the most extensive communication with all stakeholders can allow teachers to be more effective in the leadership process in schools compared to families, students and even school principals. In this leadership process, what is expected from teachers in particular is that they shape the working environment collaboratively with school principals, and this relies on a democratic process (Beachum \& Dentith, 2004). In a school environment in which cooperation and democracy are found, the leadership process maintains its functions in an effective way and the participation of stakeholders in the leadership process is encouraged.

Fast-paced change has introduced a number of new roles for teachers. It is possible to state that leadership is the determining factor compared to the other factors in the various significant teacher roles observed in the research on 
development and changes in schools (Harris \& Muijs, 2005). Dozier (2007) emphasizes that development in schools can only be possible if teachers exercise a leadership role, while Gabriel (2005) reports that teachers' leadership roles are important in experiencing an effective process of change. Teacher leadership is a leadership approach which allows creative opinions about organizational change and development processes to be exhibited, as they interact with related elements (Dağ \& Göktürk, 2014). These definitions suggest that the teacher leadership is role with influence on the school, school management, teachers and students.

One of the most distinguishing aspects of leaders is their ability to influence people around them. French and Raven (1959) suggest that influence can only be possible if there are powerful resources associated with leadership, and these resources are charisma, specialty, regulations, prizes and the ability to compel (Northouse, 2014). Robbins (1994) describes leadership as the ability to influence people in achieving goals and Freadman, Sears and Carlsmith (2003) state that the leader is the person who is most able to influence other people or groups. Teachers, who can influence their students, coworkers, school principals, parents and even the wider society, are required to employ their leadership skills to fulfill the objectives of their school at the highest possible level in order to make it an "effective school" (Turan, 2010). In the formation of effective schools, leader teachers who focus on the development of their schools, who can manage change, resolve problems, and think up alternative solutions will be the most important factors.

Specific tasks and responsibilities are expected from leader teachers. Whereas Labich (1988) claims that teachers are required to fulfill the responsibilities of trust, developing vision, keeping a level head, supporting entrepreneurship, being specialists, respecting different opinions and facilitation/facilitating learning so that they can be effective leaders, Harris and Lambert (2003) suggest that facilitating professional cooperation, organizational development and the renewal process, and developing human capacities in the organization are the most important functions of leader teachers. When leader teachers accomplish these tasks and responsibilities, schools can be pioneers of social change and innovation in society (Aydın, 2010). From this point of view, it is possible to suggest that leader teachers are a significant factor in social change.

Leader teachers are highly motivated to participate in the decision-making process at school. Leader teachers have a stronger influence in the decision-making process compared to any other group or individual teachers (Seashore Louis, Leithwood et al., 2010). Leader teachers who are sensitive about participating in the decision-making process in schools encourage their students to participate in decisions concerning the classroom (Can, 2011). From this information, it is possible to conclude that supporting a democratic process is a significant characteristic of teacher leadership.

Leader teachers are able to cooperate with everyone in order to increase a school's success and to develop teaching. Moreover, they are disposed to participate in decisions which may affect the school and students. The participation of teaching professionals in decisions related to the school, and their overt display of interest in this, will contribute to the formation of a synergy across a school. A participative and cooperative organizational structure, referred to by Heifetz and Laurie (1997) as the "collective mind" that is needed by the $21^{\text {st }}$ century schools, allows for the resolution of issues and promotes creativity. In the institutionalization of a cooperative and participant organizational structure, it is thus essential that teachers undertake leadership roles in schools.

Leader teachers can be considered as the most effective and important strength of the school. SinceKatzenmeyer and Moller (2013) characterize teacher leadership as a strong facilitator for change; they call it "a sleeping giant". Mobilization of this sleeping giant will result in successful schools. Research on successful schools suggests that teachers and students make progress in schools with a school culture that relies on cooperation and the exchange of professional opinions (Waters, Marzano \& McNulty, 2008). Leader teachers facilitate the formation and maintenance of such an organizational culture. Leader teachers play a significant role in the formation of a positive atmosphere at school and the development of a school (Danielson, 2006). Leader teachers who make the effort to develop their schools do not avoid taking responsibility for this and focus on developing their capacities (Crowther \& Olsen, 1997). Harrison and Killion (2007) report that, in terms of teachers' participation in success, significant roles are played in terms of provision of resources, teaching specialty, teaching program specialty, support in the classroom, facilitating learning, guidance, school leadership, data coaching, facilitating change and learning. A school does not attain success solely by means of teacher who seem to be carrying out their tasks correctly, but through teachers who have the skills and qualifications specified above and who can play the roles mentioned above.

Another prominent characteristic of leader teachers is their faith in success. Leader teachers believe that all of their students will be successful and they motivate their students through their successful results. They encourage their coworkers to motivate students as well (Robbins \& Ramos-Pell, 2010). The ability to motivate is a great strength utilized by leader teachers. They can mobilize and influence people with this strength.

Teacher leadership is about organizing the unutilized leadership capital already found teachers in order to influence the process of change positively at school, rather than assisting teachers to be more dominant. Applying teacher leadership 
is a collective and shared effort which provides the opportunity for all teachers to be a leader at different times (Greenlee, 2007). Leader teachers consider themselves first as teachers; they are not disposed to be a manager or school principal. However, they work in cooperation with their coworkers and school principals for the purpose of developing the school and elevating student performance (Education Commission of the States, 2010). Leader teachers focus on developing their schools. Any position, status or official role is outside their interest. It is even possible to state that they try to keep some distance from official tasks because these roles prevent them from exhibiting leadership behaviors and skills and their goal to develop the school.

Teachers can display both formal and informal leadership at school. This is result of their daily roles and arises in cooperation with other teachers, other workers and school management at the classroom, department or school level. According to Danielson (2006), teacher leadership is an informal role because it is not obtained by appointment or delegation. According to Schleicher (2012), leader teachers can undertake formal roles and responsibilities regarding school management and leadership such as curriculum leadership, auditing etc.

Leadership is one of the most important roles expected from teachers today. Teacher leadership is a significant factor in the commitment of schools to their role in guiding societies, in developing schools' positive aspects, and in managing learning in an effective way. If this is the case, it is necessary to measure and evaluate perceptions of teachers regarding this important role. The scarcity of studies concerning teacher leadership (Bayuk, 2013; Beycioglu \& Aslan, 2012; Gul, 2010; Kilinc \& Recepglu, 2013; Kolukcu, 2011) emphasizes the significance of the present study, which aims to determine the teacher leadership perception levels of teachers. It has also been emphasized by various researchers that there is need for further studies on teacher leadership (Grant, 2006; Muijs \& Harris, 2007; Zinn, 1997). The essential purpose of this study is to determine the level of teacher leadership perceptions of secondary school teachers. In addition, it is intended for determine whether the teacher leadership perceptions of secondary school teachers differ according to a number of personal variables. In order to achieve these objectives, answers were sought to the following questions:

- What is the level of teacher leadership perceptions of secondary school teachers?

- Do the teacher leadership perceptions of secondary school teachers exhibit significant difference according to their gender, age and occupational seniority variables?

\section{Method}

\subsection{Research Design}

In the present quantitative research, a general screening model was utilized for the description of the study. The screening model aims to describe the subject which is investigated according to unique terms. A general screening model is one conducted on all or a sampling of a population consisting of a number of members (Karasar, 2009).

\subsection{Research Sample}

The population of the research consisted of 564 secondary school teachers working in Kirşehir Central County. In determining the sampling, the simple random sampling method was used. In simple random sampling, all aspects have equal weight. All factors are listed during the application and they are selected randomly from the list. If a population is not too large and complex, selection can be conducted efficiently; and since statistical operations are conducted with no weighting in this sampling method, evaluation and the sampling error can be estimated without any difficulty (Kilic, 2015). The study was conducted on 376 secondary school teachers who were selected by means of the simple random sampling method from among 564 teachers who were working at secondary schools in Kırşehir Central County during the 2014-2015 Academic Year.

In the sampling estimation, the equation suggested by Buyukozturk et al. (2012) was utilized:

Equation 1: Estimation of Sampling Size in Continuous Variables

$$
n=\frac{n_{0}}{1+\frac{n_{0}}{N}}
$$

Where $\mathrm{n}_{0}=\left(\mathrm{t}^{2} \mathrm{PQ}\right) / \mathrm{d}^{2}$ and $\mathrm{pq}=0.25$ when $\mathrm{p}$ significance value is taken as 0.05 , and since the corresponding $\mathrm{t}$ value in the table is 1.96; it is estimated as $\mathrm{n}_{0}=384.16$ at the 0.05 significance level (Büyüköztürk et al., 2012). If the estimated $\mathrm{n}_{0}$ value is placed in the equation;

$\mathrm{n}=\frac{384,16}{1+\frac{384,16}{564}}$

the sample size is found to be 228.51. As the sample size was 376 in the present study, the necessary sample size for this research was exceeded. Demographic characteristics of the participant teachers are summarized in Table 1. 
Table 1. Demographic characteristics of participant teachers

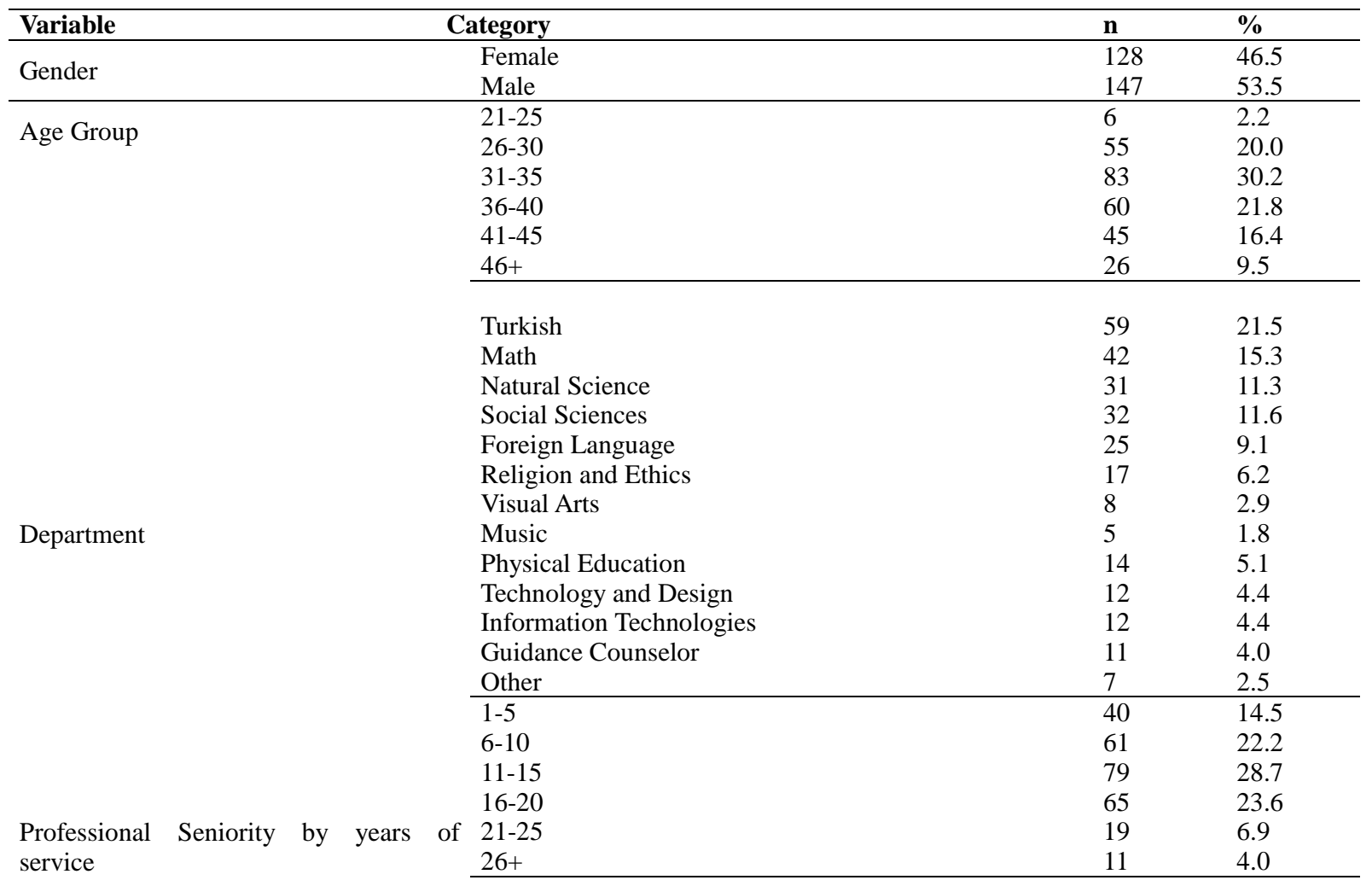

\subsection{Research Instrument and Procedure}

In this study, the "Teacher Leadership Scale" (TLS) developed by Beycioglu and Aslan (2012) was used.

Validity and reliability investigations of the TLS were conducted based on data collected concerning the sample group consisting of 317 teachers, of whom 296 were regular teachers and 21 administrative teachers. After it was determined that the data obtained was appropriate to the exploratory factor analysis with articles concerning perception (Kaiser Meyer Olkin $=.95$, Bartlett's Test of Sphericity $=5463.25 \mathrm{p}=.000$ ) and with articles concerning expectation (Kaiser Meyer Olkin $=.94$, Bartlett's Test of Sphericity $=4297.67, \mathrm{p}=.000$ ), factor analysis was conducted on the data according to the principles component analysis method. It was concluded that the scale used in the present study was valid and reliable. As a result of the exploratory factor analysis, it was determined that the scale had a structure with three factors: "institutional improvement", "professional improvement" and "collaboration among colleagues". In order to determine the reliability level, Cronbach's Alpha internal coefficient to consistence was estimated for perception as .95 and for expectation as .93. In test-retest reliability analyses, theh Pearson Correlation Coefficient was estimated for the perception dimension as .87; for the expectation dimension as .80 (Beycioglu and Aslan, 2012).

\subsection{Data Analysis}

Collected data was analyzed by the SPSS 17.0 software through descriptive statistical methods and techniques (frequency, percentage, average, standard deviation).

Whether secondary teachers' perception levels regarding teacher leadership differs according to certain variables was investigated by means of the t-test and Kruskall Wallis test.

\section{Results}

In this section, findings in line with determining respondent secondary school teachers' perception of teacher leadership and whether these perceptions exhibit significant difference according to certain personal variables are given.

\subsection{Findings Regarding Teacher Leadership Levels Perceived by Secondary School Teachers}

The teachers' perception of teacher leadership results are summarized in Table 2. 
Table 2. Descriptive statistics findings about the perception of teachers regarding teacher leadership

\begin{tabular}{lllll}
\hline & Minimum & Maximum & $\bar{X}$ & SD \\
\hline Institutional improvement & 1.11 & 5 & 3.37 & 0.83 \\
Professional improvement & 2.18 & 5 & 4.08 & 0.57 \\
Collaboration among colleagues & 1.6 & 5 & 3.92 & 0.67 \\
\hline According
\end{tabular}

According to Table 2, it can be observed that perception of teachers regarding the "institutional improvement" dimension of teacher leadership is at a medium level $(\bar{X}=3.37)$; regarding the "professional improvement" $(X=4.08)$ and the "collaboration among colleagues" $(\bar{X}=3.92)$ dimensions of teacher leadership it is at a high level. Respondent teachers are of the opinion that behaviors within the scope of "professional improvement" and "collaboration among colleagues" dimension of teacher leadership are exhibited more frequently compared to those within "institutional improvement" dimension.

\subsection{Findings Regarding Personal Variables}

The total score obtained from the scale to examine whether the perception of teacher leadership displays significant difference with respect to the gender of teachers was analyzed by means of the t-test and the relevant results are summarized in Table 3.

Table 3. Independent-sample t-test results regarding whether the teacher leadership level perceived by teachers exhibits significant differences according to their gender

\begin{tabular}{|c|c|c|c|c|c|c|}
\hline & Gender & $\mathrm{N}$ & $\bar{x}$ & Std. deviation & $\mathrm{t}$ & $\mathrm{p}$ \\
\hline \multirow{2}{*}{ Institutional improvement } & Female & 128 & 3.24 & 0.85 & \multirow{2}{*}{-2.373} & \multirow{2}{*}{$0.018 *$} \\
\hline & Male & 147 & 3.48 & 0.80 & & \\
\hline \multirow{2}{*}{ Professional improvement } & Female & 128 & 4.11 & 0.53 & \multirow{2}{*}{0.999} & \multirow{2}{*}{0.319} \\
\hline & Male & 147 & 4.04 & 0.60 & & \\
\hline \multirow{2}{*}{ Collaboration among colleagues } & Female & 128 & 3.93 & 0.64 & \multirow{2}{*}{0.247} & \multirow{2}{*}{0.805} \\
\hline & Male & 147 & 3.91 & 0.70 & & \\
\hline
\end{tabular}

$* \mathrm{p}<0.05$

According to Table 3 , the average scores of male teachers $(\bar{X}=3.48)$ for the teacher leadership "institutional improvement" dimension were greater than the average scores of female teachers $(\bar{X}=3.24)$. It was determined that secondary school teachers' perceptions regarding the "institutional improvement" dimension of teacher leadership exhibits a significant difference according to gender.

The total score obtained from the scale to examine whether the perception of secondary school teachers regarding teacher leadership exhibits significant difference according to their age was analyzed by means of the Kruskal Wallis Test. The results obtained are exhibited in Table 4.

Table 4. Kruskal Wallis results regarding whether teachers' perception of teacher leadership exhibits significant difference according to their age

\begin{tabular}{|c|c|c|c|c|c|c|c|}
\hline & & $\mathrm{n}$ & $\overline{\bar{X}}$ & $\begin{array}{l}\text { Std. } \\
\text { deviation }\end{array}$ & $\begin{array}{l}\text { Kruskal } \\
\text { Wallis Test }\end{array}$ & $\mathrm{p}$ & Significant Difference \\
\hline \multirow{6}{*}{$\begin{array}{l}\text { Institutional } \\
\text { improvement }\end{array}$} & $21-25$ & 6 & 3.91 & 0.66 & \multirow{7}{*}{12.074} & \multirow{6}{*}{0.064} & \multirow{6}{*}{ No } \\
\hline & $26-30$ & 55 & 3.10 & 0.68 & & & \\
\hline & $31-35$ & 83 & 3.35 & 0.93 & & & \\
\hline & $36-40$ & 60 & 3.43 & 0.76 & & & \\
\hline & $41-45$ & 45 & 3.54 & 0.93 & & & \\
\hline & $46+$ & 26 & 3.41 & 0.71 & & & \\
\hline \multirow{6}{*}{$\begin{array}{l}\text { Professional } \\
\text { improvement }\end{array}$} & $21-25$ & 6 & 4.09 & 0.54 & & \multirow{6}{*}{$0.020 *$} & \multirow{6}{*}{$\begin{array}{l}* 26-30 \text { and } 36-40 \\
* 26-30 \text { and } 41-45\end{array}$} \\
\hline & $26-30$ & 55 & 3.89 & 0.53 & \multirow{5}{*}{13.405} & & \\
\hline & $31-35$ & 83 & 4.04 & 0.61 & & & \\
\hline & $36-40$ & 60 & 4.25 & 0.48 & & & \\
\hline & $41-45$ & 45 & 4.18 & 0.60 & & & \\
\hline & $46+$ & 26 & 4.01 & 0.60 & & & \\
\hline \multirow{6}{*}{$\begin{array}{l}\text { Collaboration } \\
\text { among } \\
\text { colleagues }\end{array}$} & $21-25$ & 6 & 4.20 & 0.42 & \multirow{6}{*}{5.732} & \multirow{6}{*}{0.333} & \multirow{6}{*}{ No } \\
\hline & $26-30$ & 55 & 3.82 & 0.60 & & & \\
\hline & $31-35$ & 83 & 3.87 & 0.72 & & & \\
\hline & $36-40$ & 60 & 3.96 & 0.62 & & & \\
\hline & $41-45$ & 45 & 4.08 & 0.72 & & & \\
\hline & $46+$ & 26 & 3.91 & 0.70 & & & \\
\hline
\end{tabular}

According to Table 4 , the average scale scores $(\bar{X}=4.25)$ of teachers in the age group $36-40$ with respect to the "professional improvement" dimension of teacher leadership were greater than the teachers in the age group 26-30 $(X=3.89)$ and this difference is significant. It can be observed that the average scale scores of teachers $(X=4.18)$ in the 
age group 41-45 with respect to the "professional improvement" dimension of teacher leadership were greater than the average scale scores of teachers in the age group 26-30 ( $\bar{X}=3.89)$, and this difference was significant.

The total score obtained from the scale which is used to examine whether secondary school teachers' perceptions regarding teacher leadership exhibit significant difference according to their seniority was analyzed by means of the Kruskal Wallis test and the results are summarized in Table 5.

Table 5. Kruskal Wallis results regarding whether teachers' perception levels regarding teacher leadership exhibit significant difference according to their professional seniority

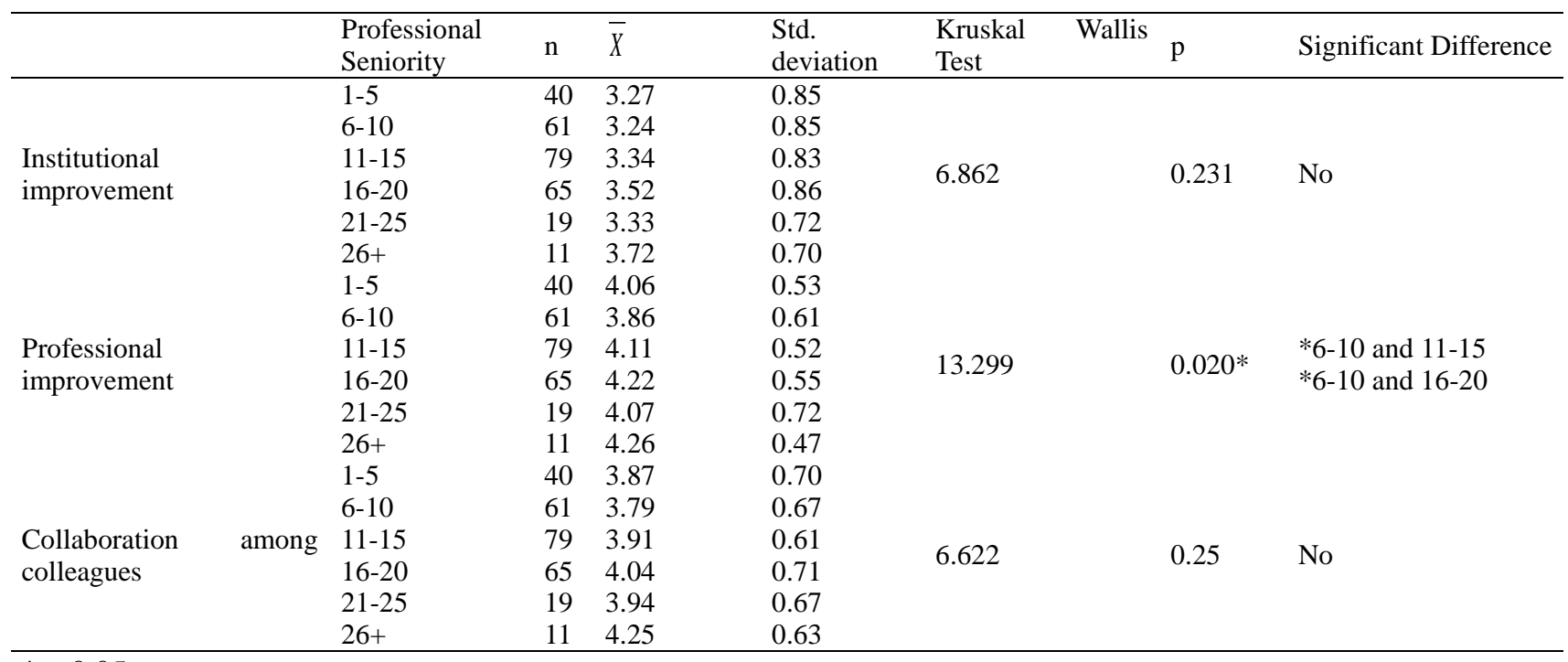

*p $<0.05$

According to Table 5, it was observed that the average scale scores of teachers in the professional seniority group who served from 11 to15 years with respect to the "professional development" dimension of teacher leadership $(\bar{X}=4.11)$ were greater than the ones in the professional seniority group of 6-10 years $(\bar{X}=3.86)$; this difference was significant. It can be concluded from Table 7 that average scale scores of teachers in the professional seniority group of 16-20 years for the "professional improvement" dimension of teacher leadership $(\bar{X}=4.22)$ were greater than the teachers in the professional seniority group of 6-10 years $(\bar{X}=3.86)$ and this difference was significant.

It was determined that secondary school teachers' perceptions regarding the "professional improvement" dimension of teacher leadership exhibit significant difference according to professional seniority. Accordingly, it is possible to suggest that as occupational seniority increases, teachers' perceptions regarding teacher leadership increase, and teachers in the occupational seniority groups of 11-15 and 16-20 spend more time on professional improvement activities; in other words, these teachers care more about professional improvement.

\section{Discussion, Conclusion and Recommendations}

\subsection{Discussion}

The present study aimed to determine the teacher leadership perceptions of secondary school teachers. It can be considered as a limitation in terms of our study that there is a lack of research investigating teacher leadership in both domestic and foreign literature, which introduces difficulty in making clear the relationships among the results of existing studies in the relevant literature.

In the present research, it was revealed that secondary school teachers' perceptions regarding the "institutional improvement" sub-dimension was at a medium level. This finding can be assessed as negative. In the study conducted by Kilinc and Recepoglu (2013), it was reported that secondary school teachers' perception regarding the "institutional improvement" sub-dimension was lower than the perceptions regarding the other sub-dimensions. Institutions need to develop in order to increase their productivity and to cope with change. Institutions which cannot maintain their development lose the function of fulfilling the needs of their society and the individuals in it. Thus, they lose their efficiency and reliability and face entropy. There may be a number of internal and external factors which effect the development of institutions. Amongst them, the most important one is the human factor, the people who use their intelligence and knowledge to manage resources and technology and who process inputs and transform them into outputs. For schools, which fulfill the responsibility of training and educating individuals within a society, teachers are the most essential resource due to their roles as educational practitioners. It is thus necessary that teachers fulfill the 
responsibilities expected from them regarding the efficient development of their schools. As one of the most important indicators of teacher leadership, teachers are required to pay the utmost attention to the issue of how to improve schools.

The low perception levels of secondary school teachers regarding the teacher leadership "institutional development" sub-dimension could be result of their ignorance about how to help their institutions develop or face theobstacles in their efforts related to institutional development behaviors. Yet, it has been reported by researchers that there could be factors which would be effective in changing teachers' leadership behaviors (DuFour, Eaker \& DuFour, 2005; Hook, 2006; Mangin, 2007). The reason for the low level of perception of secondary school teachers regarding the teacher leadership "institutional improvement" sub-dimension could be their low level of commitment to the institution. When it is considered that the institutional commitment of employees is an indicator of organizations' consistent success and wellbeing (Luthans, 1992), it is possible to suggest that teachers who do not give sufficient time to development of their institutions do not feel a sense of institutional commitment or their institutional commitment levels are low.

It was determined that secondary school teachers' perceptions regarding the "institutional improvement" dimension of teacher leadership exhibit significant difference according to gender. This finding can be interpreted as showing that male teachers spend more time on the institutional development of their schools; they internalize the teacher leadership "institutional improvement" sub-dimension behaviors more; and they care about the institutional improvement of their schools.

Teachers in age group 36-40 with respect to hte "professional improvement" dimension of teacher leadership had greater scores than the teachers in the age group 26-30 and this difference is significant. It can be observed that the average scale scores of teachers in the age group 41-45 with respect to the "professional improvement" dimension of teacher leadership were greater than the average scale scores of teachers in the age group 26-30 and this difference was significant. Accordingly, it is possible to suggest that as teachers' age increases, teachers' perceptions of teacher leadership increase, teachers in the age groups 36-40 and 41-45 spend more time on professional improvement; in other words, these teachers care more about professional improvement.

It was determined that secondary school teachers' perceptions regarding the "professional improvement" dimension of teacher leadership exhibit a significant difference according to professional seniority. Accordingly, it is possible to suggest that as occupational seniority increases, teachers' perceptions regarding teacher leadership increase and teachers in the occupational seniority groups of 11-15 and 16-20 years spend more time on professional improvement activities; in other words, these teachers care more about professional improvement.

\subsection{Conclusions}

Teachers' perceptions regarding teacher leadership for the "institutional improvement" sub-dimension was determined as being at a medium level; perceptions concerning "professional improvement" and "collaboration among colleagues" sub-dimensions were determined as being at a high level.

Teachers' perceptions regarding teacher leadership in terms of the "institutional improvement" sub-dimension exhibited a significant difference in male teachers.

Teachers' perceptions regarding teacher leadership in terms of the "professional improvement" sub-dimension exhibited a significant difference according to age and occupational seniority.

\subsection{Recommendations}

- It is necessary to enhance institutional commitment levels of teachers so that their perception regarding the teacher leadership "institutional improvement" sub-dimension can be developed.

- It is necessary to provide training to teachers and teacher candidates for instructional leadership and teacher leadership areas.

- Teachers' leadership skills and behaviors must be particularly supported by school principals.

- Further research investigating the effect of teacher leadership on the development of schools, the effectiveness of school principals, and on the development of students is required.

- Teachers' leadership must be investigated in terms of theirrelations with specific leadership skills.

\section{References}

Anderson, K. D. (2004). The nature of teacher leadership in schools as reciprocal influences between teachers and principals. School Effectiveness and School Leadership, 15(1), 97-113. https://doi.org/10.1076/sesi.15.1.97.27489

Aydin M. (2010). Educational Administration. Istanbul: Hatiboglu Printing and Publication Company.

Bayuk, K. (2013). The research of relationship between class management skills and leadership attitudes of primary 
school teachers. Unpublished Master Thesis. Istanbul: Yeditepe University Institute of Social Sciences.

Beachum, F., \& Dentith, A. M. (2004). Teacher leaders creating cultures of school renewal and transformation. The Educational Forum, 68(3), 276-286. https://doi.org/10.1080/00131720408984639

Beycioğlu, K., \& Aslan, B. (2012). Educational Administration: Theory and Practice, 18(2), 191-223.

Buyukozturk, S., Cakmak, E. K., Akgun, O. E., Karadeniz, S., \& Demirel, F. (2012). Scientific research methods. Ankara: Pegem Publication.

Can, N. (2011). Teacher as a leader in the classroom. In, M. Sisman \& S. Turan (Ed.), Classroom management (p.225-240). Ankara: Pegem A Publishing.

Crowther, F., \& Olsen, P. (1997). Teachers as leaders - an exploratory framework. International Journal of Educational Management, 11(1), 6-13. https://doi.org/10.1108/09513549710155410

Dag, I., \& Gokturk, T. (2014). Leadership in classroom management and contributions of leadership for classroom management. International Journal of Social Science, 27, 171-184.

Danielson, C. (2006). Teacher leadership that strengthens professional practice. Alexandria: ASCD.

Dozier, T. K. (2007). Turning good teachers into great leaders. Educational Leadership, September, 54-58.

DuFour, R., Eaker, R., \& DuFour, R. (2005). Recurring themes of professional learning communities and the assumptions they challenge. In R. DuFour, R. Eaker ve R. DuFour (Ed.), On common ground: The power of professional learning communities (1-6). Bloomington, IN: Solution Tree.

Education Commission of the States (2010). Teacher leaders: boosting teacher effectiveness and student achievement. The Progress of Education Reform. Denver: 11(6). Retrieved October 15, 2015, from http://www.betterhighschools.org/MidwestSIG/documents/Handout_TeacherLeaders.pdf

Freadman J. L., Sears D. O., \& Carlsmith J. M. (2003). Social Psychology. Translated by: A. Dönmez. Ankara: İmge Publication.

Fullan, M. G. (1994). Teacher leadership: a failure to conceptualize. In D. R. Walling (Ed.), Teachers as leaders (241-253). Bloomington, IN: Phi Delta Kappa Educational Foundation.

Gabriel, J. G. (2005). How to thrive as a teacher leader. Alexandria: ASCD.

Grant, C. (2006). Emerging voices on teacher leadership: some South African view. Educational Management Administration \& Leadership, 34(4), 511-532. https://doi.org/10.1177/1741143206068215

Greenlee, B. J. (2007). Building Teacher leadership capacity through educational leadership programs. Journal of Research for Educational Leaders, 4(1), 44-74.

Gul, R. (2010). The ideas of the teachers' leadership from republic to nowadays. Unpublished Master Thesis. Tokat: Gaziosmanpasa University Institute of Social Sciences.

Hallinger, P. (2005). Instructional leadership and the school principal: A passing fancy that refuses to fade away. Leadership and Policy in Schools, 4(3), 221-239. https://doi.org/10.1080/15700760500244793

Harris, A. (2004). Editorial: School leadership and school improvement: a simple and a complex relationship. School Leadership and Management, 24, 3-5. https://doi.org/10.1080/1363243042000172778

Harris, A., \& Lambert, L. (2003). Building leadership capacity for school improvement. Maidenhead, Philadelphia: Open University.

Harris, A., \& Muijs, D. (2005). Improving schools through teacher leadership. London: Open university press.

Harrison, C., \& Killion, J. (2007). Ten roles for teacher leaders. Educational Leadership, September 2007, 65(1), Teachers as Leaders Pages 74-77. Retrieved October 10, 2015, from http://www.ascd.org/publications/educational-leadership/sept07/vol65/num01/Ten-Roles-for-Teacher-Leaders.aspx

Heifetz, R., \& Laurie, D. (1997, January/February). The work of leadership. Harvard Business Review, 75(1), 124-134.

Hook, D. P. (2006). The impact of teacher leadership on school effectiveness in selected exemplary secondary schools. Doctoral Dissertation, Texas A\&M University. ProQuest Dissertations and Thesis data base. (UMI No. 3219160).

Karasar, N. (2009). Scientific research method. Ankara: Nobel Publication, Distribution.

Katzenmeyer, M., \& Moller, G. (2013). Awakening the sleeping giant: helping teachers develop as leaders. Translated By: A. C. Kilinc. Ankara: Nobel Publication, Distribution.

Kolukcu, D. (2011). Necessity of demonstrating leadership for elementary school teachers and their views relating to 
the level of demonstrating leadership. Unpublished Master Thesis. Ankara: Baskent University Institute of Educational Sciences.

Kilic, S. (2015). Sampling methods. Retrieved July 7, 2015, from http://jmood.org/pdf/EN-JMOOD-f384d225.pdf

Kilinc, A. C., \& Recepoglu, E. (2013). High school teachers' perceptions on and expectations from teacher leadership. Kalem, the education and human sciences journal, 3(2), 175-215.

Kuran, K. (2005). The relationhip between total quality management and active learning as a change and development process. Journal of Cagdas Egitim, 317, 14-22.

Labich, K. (1988). The seven keys to business leadership. Retrieved January 6, 2015, from http://archive.fortune.com/magazines/fortune/fortune_archive/1988/10/24/71165/index.htm

Luthans, F. (1992). Organizational behaviour. Mcgraw-Hill, 6th Edition.

Mangin, M. M. (2007). Facilitating elementary principals' support for instructional teacher leadership. Educational Administration Quarterly, 43(3), 319-357. https://doi.org/10.1177/0013161X07299438

Northouse, P. G. (2014). Leadership: theories and practices. Translated By: C. Simsek. Izmir: University of Surat Publication.

Muijs, D., \& Harris, A. (2007). Teacher leadership in action. three case studies of contrasting schools. Educational Management Administration \& Leadership, 35(1), 111-134. https://doi.org/10.1177/1741143207071387.

Robbins, P. (1994). Basis of organizational behaviours. Translated By: S.A. Ozturk. Eskisehir: Etam Company.

Robbins, P., \& Ramos-Pell, A. (2010). Shared leadership: a key to student achievement in an underperforming school teacher leadership. A publication of the University of Phoenix. Retrieved April 12, 2011, from http://cdnstatic.phoenix.edu/content/dam/altcloud/doc/Teacher_Leadership_White_Paper.pdf\#_blank

Seashore, L. K., Leithwood, K., et al. (2010). Learning from leadership: investigating the links to improved student learning. Final Report to the Wallace Foundation. Minneapolis, MN: University of Minnesota. Retrieved July 6, 2015, from

http://www.wallacefoundation.org/KnowledgeCenter/KnowledgeTopics/CurrentAreasofFocus/EducationLeadershi $\mathrm{p} /$ Documents/Learning-from-Leadership-Investigating-Links-Final-Report.pdf

Schleicher, A. (2012). Ed., Preparing Teachers and Developing School Leaders for the 21st Century: Lessons from around the World, OECD Publishing. Retrieved November 9, 2015, from http://dx.doi.org/10.1787/9789264xxxxxx-en

Turan, S. (2010). Educational administration, theory, research and practice. Ankara: Nobel Publication, Distribution.

Waters, T., Marzano, R. J., \& McNulty, B. (2008). Balanced Leadership: What 30 years of research tells us about the effect of leadership on student achievement. Denver, CO: Mid-Continent Research for Education and Learning.

Zinn, L. F. (1997). Supports and barriers to teacher leadership reports of teacher leaders. Paper presented in the Annual Meeting of American Educational Research Association. Chicago, IL, (24-28 Mart, 1997).

\section{Copyrights}

Copyright for this article is retained by the author(s), with first publication rights granted to the journal.

This is an open-access article distributed under the terms and conditions of the Creative Commons Attribution license which permits unrestricted use, distribution, and reproduction in any medium, provided the original work is properly cited. 